\title{
AUTOIMMUNE GLOBULINS IN SYSTEMIC LUPUS ERYTHEMATOSUS
}

\author{
YOSHIHIRO HAMASHIMA* \\ Department of Pathology, Kyoto University, Kyoto \\ AND TATSUO ODAKA** \\ Department of Dermatology, Kyoto University Hospital, Kyoto
}

(Received: August 22nd, 1964)

This paper presents an investigation on the interaction of the so-called " antinuclear antibodies" in the serum of systemic lupus erythematosus (SLE) with nucleic acid.

Miescher and co-workers $(1954,1957,1957)$ found that the LE factor was specifically absorbed by purified nucleoprotein and DNA, and the reactivity of the antinuclear antibodies with nucleus, nuclear derivatives and DNA was demonstrated by most of the classical immunological techniques, including precipitation (Deicher et al., 1959; Seligmann, 1958), complement fixation (Ceppelini et al., 1957 ; Hijimans and Schmit, 1961 ; Pearson et al., 1958; Holman and Deicher, 1957 ; Robbins et al., 1957), tanned red cell hemagglutination (Miescher and Strässle, 1957; Lee and Epstein, 1960), passive cutaneous anaphylaxis (Deicher et al., 1960), and immunofluorescence (Friou et al., 1958; Friou, 1958 ; Holman and Kunkel, 1957 ; Holborow et al., 1957 ; Bardawil et al., 1958).

Bardawil et al. (1958) and Seligmann (1958) consider that anti-DNA antibodies are fundamentally, if not exclusively, concerned in the pathogenesis of SLE and cause diffuse nuclear damage which could constitute the basic anatomical lesion of SLE.

\section{MATERIALS AND METHODS}

Sera from 18 patients with acute and subacute SLE and their families were used for the agardiffusion test, immunoelectrophoresis, immunofluorescence and ultracentrifuge method.

Antigens : $3-4 \mathrm{~kg}$ albino rabbits were immunized with purified $45 \mu \mathrm{g}$ DNA-phosphorus (salmon sperm, Sigma Co.), $60 \mathrm{mg}$ of histone (calf thymus, crystallyzed preparation from Worthington Chemical Corporation), for use in the agar diffusion test, precipitin tube test, and blocking test of immunofluorescence on the section.

A half milliliter of a DNA solution containing $50 \mu \mathrm{g}$ phosphorus $/ \mathrm{ml}$ was mixed with $0.25 \mathrm{ml}$ of a DNase solution of $0.1 \mathrm{mg} / \mathrm{ml}$ in a pH 6.8 phosphate buffer containing $5 \mu \mathrm{M} \mathrm{MgCl}_{2}$. The mixture was incubated at $37^{\circ} \mathrm{C}$ for 60 minutes. Bovine pancreatic RNase was used as a control material.

DNA preparation: Salmon sperm DNA was obtained commercially from Sigma Co., U. S., and consisted of $8.02 \%$ phosphorus analytically and $2.8 \%$ protein as measured by a modified nesslerization (nitrogen micro-determination) and Folin method.

Immunization: Groups of albino rabbits weighing $2.0-2.5 \mathrm{~kg}$ were immunized intramuscularly with $45 \mu \mathrm{g}$ (phosphorus) DNA, $45 \mu \mathrm{g}$ (phosphorus) DNA-120 mg Progesteron combination, or 45 $\mu \mathrm{g}$ (phosphorus) DNA-rabbit $7 \mathrm{~S}$ gamma globulin $(40 \mathrm{mg})$ combination of incomplate Freund's

* 浜島 義博 (京都大学医学部病理学教室)

**尾高 達雄（京都大学医学部皮膚科教室） 
adjuvant. Booster injections were done intravenously 4 months later from the first response.

RNA preparation: Highpolymerized salmon sperm RNA was obtained commercially from Nakarai Chemical Corp., Kyoto, Japan, and purified by $\mathrm{HCl}$ fractionation method. Five hundreds mg of RNA was dissolved in $5 \mathrm{ml}$ of phosphate buffered saline (pH 7.2), and was mixed with $5 \mathrm{ml}$ of octanolchloroform solution (10\% octanol, $90 \%$ chloroform).

The mixture was shaken vigorously for 30 minutes in a cold room, spun at $1000 \mathrm{rpm}$ for 20 minutes at $4^{\circ} \mathrm{C}$, and the supernatant was diluted with an equal amount of $10 \%$ octanol-chloroform solution, and then the mixture was shaken again for 30 minutes in the cold room.

This step was repeated until the mid-layer between octanol and RNA solution became transparent. The final supernatant was diluted 3 times with $0.05 \mathrm{~N} \mathrm{HCl-ethylalcohol,} \mathrm{left} \mathrm{standing}$ in the cold room for 1 hour, and spun at $1000 \mathrm{rpm}$ for 30 minutes. The precipitate was dissolved in phosphate buffered saline $(\mathrm{pH} 7.2)$, and measured for the mole amount by a spectrophotometer at the wavelength of $260 \mathrm{~m} \mu$.

Agar-diffusion test: A modified Ouchterlony technique (1953) was used employing 1 per cent agar in $0.15 \mathrm{M} \mathrm{NaCl}$.

Immunoelectrophoresis : A modification of the original method of Graber and Williams (1957) was employed using $1 \%$ agar in a veronal buffer of $\mathrm{pH} 8.6$ and an ionic strength of 0.05 .

Serum samples were put into a small well $(0.1 \mathrm{ml})$ and electrophoresis was then performed at room temperature at 250 volts and $50 \mathrm{~mA}$ for 2 hours.

After completion of the separation, rabbit antiserum against human whole serum was filled into a long well cut out parallel to the separated serum. Usually, normal human serum was also put simultaneously into a similar well on the other side of the separated serum as a control.

Immunofluorescence: Immunofluorescent technique was used for detection of antinuclear antibodies in the serum materials by indirect method.

Fresh organ-specimens were obtained by 18 autopsy cases of SLE and 12 hyperglobulinemic diseases. The kidney, liver, spleen, thymus, brain, heart, adrenal, lung and skin were investigated. These fresh specimens $(2 \mathrm{~mm}$ thickness $\times 10 \mathrm{~mm}$ width) were fixed in cold $95 \%$ ethylalcohol for 12 hours in a refrigerator, dehydrated in cold absolute alcohol for 2 days, and then embedded in paraffin by routine method.

The paraffin sections were incubated with $1 / 16$ diluted serum material and then stained with anti-human-gammaglobulin fluorescent conjugate.

\section{RESULTS}

\section{Antinuclear Antibodies against a Solution of Purified Salmon Sperm DNA in Gel Diffusion}

A definite wide band was observed in the Ouchterlony agar plate between SLE sera and $12.4 \mu \mathrm{g}$ DNA-phosphorus/ml solution. However, when the same dose of DNA was absorbed with $1 / 50$ dose of DNase as a control, no band was observed (Plate-Fig. 1). None of the patients sera ( 6 in 18 cases) which reacted with DNA reacted with nucleohistone, nucleoprotamine, RNA or RNase in the gel-diffusion tests.

In the genetic aspects in SLE, 6 families out of 18 patient's cases, gave us particularly interesting results (Text-Fig. 1). In two patients' families (one patient was a 19 yearold daughter, and the other a 21 year-old daughter), typical anti-nuclear antibodies against DNA-protein were found in their mothers' sera who have never shown any clinical signs of the collagen diseases historically ( $\square$ and $\square$ in Text-Fig. 1) (PlateFig. 2).

In one family a 25 year-old son has suffered from SLE without antinuclear antibodies, and his younger brother (16 years old) showed antinuclear antibodies in the immunofluorescent tests and agar-diffusion test. He had experienced no severe sickness except measles since his birth up to present ( in Text-Fig. 1).

From these results, there might be "an hereditary basis" on its pathogenesis under some particular system of immunological homeostasis. 
Anti-nuclear Phenomenon
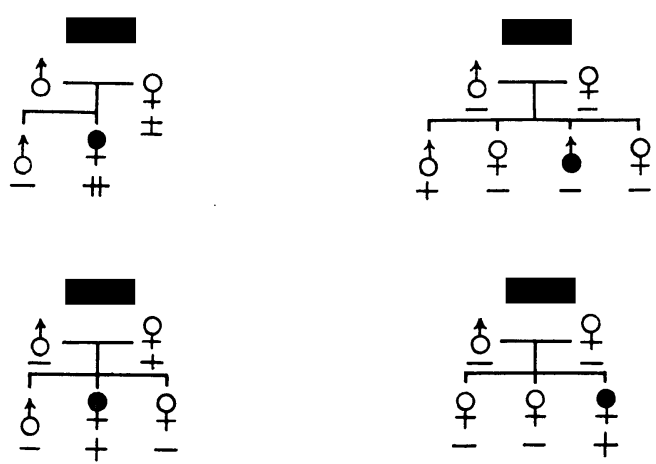

Text-Fig. 1. Genetic aspects of antinuclear phenomenon. Two mothers of $\square$ and $\square$ family, and yonger brother of family have typical anti nuclear antibodies.

Anticytoplasmic Antibodies in SLE

Sera of two out of 18 SLE showed one clear sharp band against cytoplasmic fraction from human liver cells in the agar diffusion test.

This antibody also reacts with the mitochondrial fraction from the rat liver (PlateFig. 3), and not with the microsome fraction.

By means of immunofluorescent technique, these patients' sera reacted to the cytoplasm and nuclei of the tubulareipithelium of the SLE kidney (Plate-Fig. 4), and of nerve cells in the LE neuropathic brain (Plate-Fig. 5).

\section{Antinuclear and Anticytoplasmic Factors in SLE Globulins}

All of these factors belong to $\gamma$-globulins immunoelectrophoretically and ultracentrifugically. The antinuclear factor is contained in $\gamma_{2}$-globulin and the anticytoplasmic factor is contained in both $\gamma_{2}$-globulin and $\gamma_{1}$-macroglobulin.

Plate-Fig. 6 a shows that the antinuclear ( $\gamma_{2}$-globulin) factor in SLE serum is absorbed completely with $18 \mu \mathrm{g}$ DNA-phosphorus $/ \mathrm{ml}$, but the anticytoplasmic factor in $\gamma_{1}$-macroglobulin is not absorbed with DNA. In this study, $0.15 \mathrm{ml}$ of SLE serum containing antinuclear and anticytoplasmic antibodies was added a DNA solution containing $18 \mu \mathrm{g}$ DNA-phosphorus, incubated for 2 hours at $37^{\circ} \mathrm{C}$, and kept in a cold room for 24 hours. After the serum was spun at $4500 \mathrm{rpm}$ for 20 minutes at $3^{\circ} \mathrm{C}$, the supernatant was put into a small well of immunoelectrophoretical agar.

In the upper site of the Plate-Fig. $6 \mathrm{a}$ is an SLE case, the serum without the treatment by DNA shows no absorption, but in the lower site the serum treated with DNA shows no band of $\gamma_{2}$-globulin due to absorption of antinuclear antibodies by added DNA. The lower picture of this Plate-Fig. $6 \mathrm{~b}$ shows no particular finding and no absorption in the case of normal human serum as a control of Plate-Fig. $6 \mathrm{a}$.

In three patients, $19 \mathrm{~S}$ macroglobulins were demonstrated by ultracentrifuge method, as shown in Plate-Fig. 7. These macroglobulins reacted with cytoplasm antigen of leucocytes by means of fluorescent antibody indirect technique, but not reacted with nucleohistone or nucleoprotamine antigen.

The macroglobulin is contained in $\alpha_{2}$ globulin of patients' sera (Plate-Fig. 8). 


\section{Autologous and Homologous Stainings by Means of Immunofluorescent Technique on the Tissue-Sections Obtained from SLE Autopsies}

Tissue specimens $(2 \mathrm{~mm}$ thickness $\times 10 \mathrm{~mm}$ square) of the kidney, liver, heart, spleen, lymph node, lung, brain, adrenal, ovary, testis and thymus were obtained from 6 autopsy cases of SLE within 3 hours after death. All of the patients had antinuclear antibodies and 4 of them had suffered from lupus neuropathy.

The tissues were fixed immediately with cold $95 \%$ ethylalcohol and embedded in paraffin under Sainte-Marie's procedure (1962).

Direct and indirect methods of fluorescent antibody technique were used, the indirect method for observation of the self nuclear antigenicity in autologous organ cells, and the direct method by anti-SLE 7S $\gamma$-globulin and anti-19S globulin-conjugates for observation of the immunological mechanism and the origin of forbidden clones in lymphoid tissues.

The deparaffinized sections were incubated with $1 / 16$ diluted, similar patients' sera or other patients' sera containing antinuclear antibodies for 2 hours at $37^{\circ} \mathrm{C}$, washed out with cold phosphate buffered saline $(\mathrm{pH} 7.2)$, and then stained with anti-human gammaglobulin conjugate.

\section{Antinuclear Reaction in Autologous Tissue Sections}

Sections were incubated with whole serum, the 7S-globulin and macroglobulin fractions obtained from the similar patients' sera by DEAE-cellulose fractionation method. Manifestation of the specific nuclear staining in autologous cells was observed in the kidney, hepatic mesenchymal cells, brain, pancreas, skin, and bone marrow ; and weakpositive nuclear staining was observed in the lymphoid tissues including the spleen and thymus, lung and hypophysis. Negative nuclear staining was seen in the muscle fibers of both the smooth- and striated muscles, adrenal, and fat tissue.

\section{Kidney}

Nuclei of the endothelial cells and basement cells in the glomerular tufts showed bright fluorescence in all cases; however, in the glomeruli, which had some nephritic damages like a wire-loop lesion, the nuclear fluorescence in these cells was weaker than in the intact cells. Fibroblasts nuclei of fibrous crescents reacted with antinuclear antibodies remarkably. Nuclei of the tubular epithelium showed manifest bright fluorescence, as shown in Plate-Fig. 4. In the cytoplasm of these tubular epithelium in the same figure, fine granules which reacted with patients' $\gamma$-globulin were recognized. These granules might be cytoplasmic constituents concerned with anticytoplasmic antibodies in patients' sera.

\section{Brain}

The histological findings of the central nervous system abnormalities in SLE is still unknown. In an attempt to autologous nuclear reaction in the brain sections by means of immunofluorescent technique, fine granules or granular aggregates like nuclear debris in the lumen of the cerebral blood vessel were recognized as bright fluorescence which seemed to be a particular findings. And the cytoplasm of the nerve cells reacted with patients' sera, as shown in Fig. 6, but no fluorescence was seen in the nuclei of the glial cells. 


\section{Liver}

Most of the nuclei of the parenchymal cells of the liver reacted specifically with antinuclear antibodies of patients' sera, and were not reactive with anticytoplasmic antibodies, while Kupffer's cells and reticuloendothelial cells in the sinusoids also showed no fluorescence. The nuclei or some cytoplasms of the leucocytes in the sinusoids showed bright fluorescence.

\section{Spleen and Other Lymphoid Tissues}

Main fluorescence on the sections of the spleen, lymph node and thymus of SLE was seen in the nuclei of leukocytes. The reactivity of the nuclei in the reticulum cells with autologous antinuclear antibodies was very weak, whereas only slight fluorescence was recognized in the nuclei of the reticulum cells. No fluorescence was seen in the nuclei and cytoplasms of plasma cells, lymphocytes or monocytes in affected tissues.

Most of hematoxylin bodies which were of a nuclear size, staining purple with hematoxylin in the spleen, showed bright fluorescence by the indirect method after 2 hours' incubation with the self serum.

\section{Bone Marrow}

Mainly, the nuclei of myeloblasts, promyelocytes, myelocytes, leucocytes in the bone marrow react with the antinuclear factor. The nuclei of reticulum cells, the capillary endothelium, lymphocytes, monocytes and plasmacytes did not react with it.

\section{Immune Response of the SLE Spleen Tested by Means of Fluorescent Antibody Method}

Paraffin sections of the SLE spleen were stained with anti-SLE $7 \mathrm{~S} \gamma$-globulin conjugate and observed for the morphological pattern of immunoresponsible cells. Most of the immune cells were plasmoblasts having large nuclei adjacent to the reticulum fiber. Reticulum cells were not fluorescent. (Plate-Fig. 8)

\section{Experimental Production of Antinuclear Antibodies}

Several kinds of purified nuclear constituents (DNA, RNA, histone, protamine, DNase, and RNase) were used as antigens in attempts to rise antinuclear antibodies in rabbits. All of these antigens except denaturated DNA and DNase failed to produce specific antibodies against each antigen.

For the series of DNA-immunization, three different antigens (denaturated DNA, DNA-progesterone combination and DNA-7S $\gamma$-globulin) were injected into 34 albino rabbits. Twenty rabbits were immunized with the single antigen of denaturated DNA. DNA-antibodies were obtained from only two rabbits, and the antibody amounts were $23 \mu \mathrm{gN} / \mathrm{ml}$ and $21.2 \mu \mathrm{gN} / \mathrm{ml}$ when tested by the method of precipitin curve.

Eight rabbits were immunized with DNA-progesterone combination, and antibody amounts against this antigen were $33.1 \mu \mathrm{gN} / \mathrm{ml}$ and $18.6 \mu \mathrm{gN} / \mathrm{ml}$ in 2 antisera out of 8 . rabbits.

Six rabbits were immunized with DNA-7S $\gamma$-globulin combination, and antibodies were obtained from all antisera of these 6 rabbits, ranging between $134.6 \mu \mathrm{gN} / \mathrm{ml}$ and $109.0 \mu \mathrm{gN} / \mathrm{ml}$ in a test by the method of precipitin curve.

The blood smears of normal rabbits were dried by a fan at room temperature for 10 
minutes, fixed with $95 \%$ ethylalcohol and dried again at $37^{\circ} \mathrm{C}$ for 30 minutes. The smears were washed with cold phosphate-buffered saline $(\mathrm{pH} 7.2)$, incubated with the anti-denaturated DNA rabbit sera at $37^{\circ} \mathrm{C}$ for two hours and stained with anti-rabbit $\gamma$-globulin fluorescent conjugate (sheep). The swollen nucleus of the leucocyte showed bright fluorescence, as seen in Plate-Fig. 8. The nuclei of the normal rabbit liver cells and alveolar epithelium of the lung reacted with its antisera, but paraffin sections of the human liver, lung, and spleen did not react with the rabbit antisera.

\section{DISCUSSION}

The patients with neuropathological findings who have the antinuclear antibodies often have no good prognosis clinically. Substances that have the properties of antibodies and react with DNA from various sources are frequently found in the sera of patients with SLE.

They appear to be formed spontaneously, perhaps as autoantibodies, but the stimulus for their productions is not known.

Most of these antinuclear antibodies react with the nuclei of autologous, homologous and heterologous cells, but anticytoplasmic antibodies have also been found in some patients' sera. It was shown in our study that the anticytoplasmic antibodies reacted with the mitochondrial fraction of human hepatic cells and also reacted with the mitochondrial fraction of rat liver cells. They did not react with the microsomal fraction. The fact that the antibodies react with the mitochondria of different species such as the rat liver, may probably mean that they react with DNA localized in the cytoplasm and not with cytoplasmic constituents, because, in general, the mitochondrial fraction from the liver shows a species specificity.

All of these antibodies against DNA in the nucleus or in the cytoplasm, are contained in $\gamma_{2}$-globulin of the patients' sera. Macroglobulin is contained in $\beta_{2 \mathrm{M}}$ globulin immunoelectrophoretically. However, the nature of this macroglobulin is unknown.

By our experimental results, the antinuclear antibodies were obtained from rabbits which were immunized with denaturated DNA-progesterone combination or denaturated DNA-gamma globulin combination and was detectable by the experimental antinuclear phenomenon in the nucleus of the blood leucocytes obtained from normal rabbits.

By this result, nuclear substances concerning lupus erythematosus phenomenon, that is antinuclear phenomenon, seen to have great responsibility for the production of particular antinuclear antibodies by denaturated DNA when it combines with progesterone or gamma globulins.

Butler et al. (1962) and Tanenbaum and Beiser (1963) described that they obtained experimentally purine-specific antibodies and pyrimidine-specific antibodies which reacted with DNA in rabbits.

Considerable evidence exists that these circulation antibodies are not primarily responsible for cell damage in the patient, but they may contribute to some of the pathological findings after an initial injury to the cell has occurred. It appears that these antibodies are by-products of an abnormal immune system rather than direct pathogenic agents themselves.

The immune response in such patients as SLE may originate from some pathological disturbances of mesenchymal cells including the antibody forming cells. In the spleen, lymph node and bone marrow in the patient have some unusual form of immune response to produce particular antibodies, in addition to the usual antibody. 


\section{SUMMARY}

In this paper, the interaction of antinuclear and anticytoplasmic antibodies in the serum of SLE with DNA, genetic aspects of this disease, and experimental productions of antinuclear antibodies in immunized rabbits with denaturated DNA-protein combination or denaturated DNA-progesteron combination, are discussed.

These autoimmune globulins are contained in $\gamma_{2}$-globulin. Macroglobulins were found in three patients' sera out of 18 cases of SLE, but the macroglobulin did also react with the cell nuclei when tested by means of immunofluorescent technique. Two mothers of SLE female patients and one younger brother of an SLE male patient showed antinuclear antibodies in their sera. There might be a "hereditary basis" in the system of dysresponse in the body.

The authors are much indebted to Miss Emiko Okushima and Miss Masako Saito for technical assistance.

\section{REFERENCES}

Bardawil, W. A., Toy, B. L., Galius, N. \& Bayles, T. B. (1958) : Disseminated lupus erythematosus, scleroderma, and dermatomyositis as manifestations of sensitization to DNAprotein. I. An immunohistological approach. Am. J. Path., 34, 607.

Butler, V. P., Beiser, S. M., Erlanger, B. F., Tanenbaum, S. W., Cohen, S. \& Bendich, A. (1962): Purine-specific antibodies which react with deoxyribonucleic acid (DNA). Proc. Nat. Acad. Sci., 48, 1597-1602.

Ceppelini, R., Polli, E. \& CeladA, F. (1957) : A DNA reacting factor in serum of a patient with lupus erythematosus diffusus. Proc. Soc. Exp. Med., 96, 572.

Deicher, H. R. G., Holman, H. R. \& Kunkel, H. G. (1959): The precipitin reaction between DNA and a serum factor in systemic lupus erythematosus. J. Exp. Med., 109, 97.

Deicher, H. R. G., Holman, H. R., Kunkel, H. G. \& Ovary, Z. (1960) : Passive cutaneous anaphylaxis reactions with a systemic lupus erythematosus serum factor and isolated DNA. J. Immunol., 84, 106.

FrIOU, G. J., FINCH, S. \& DETRĚ, K. (1958): Interaction of nuclei and globulin from lupus erythematosus serum demonstrated with fluorescent antibody. J. Immunol., 80, 324 .

FRIOUS, G. J. (1958): Identification of the nuclear component of the interaction of lupus erythematosus globulin and nuclei. J. Immunol., 80, 476.

Grabar, P. \& Williams, C. A., JR. (1957): Méthode immunoelectrophorétique dánalyse de mélanges de substances antigéniques. Biochem. et Biophysica Acta., 17, 67.

HAMASHIMA, Y. (1964) : Immunofluorescent study on systemic lupus erythematosus. Allergy, 13, 315.

Holborow, E. J., WeIr, D. M. \& Johnson, G. D. (1957) : A serum factor in lupus erythematosus with affinity for tissue nuclei. Brit. Med. J., 2, 732.

Holman, H. R. \& Kunkel, H. G. (1957): Affinity between the lupus erythematosus serum factor and cell nuclei and nucleoprotein. Science, 126, 162.

Holman, H. R. \& Deicher, H. R. (1957): The reaction of the lupus erythematosus serum factor and cell nuclei and nucleoprotein. Science, 126, 162.

LEE, S. L. \& EPstein, W. V. (1960) : Hemagglutination study of serum factors related to L. E. cell formation. Arth. and Rheumat., 2, 41.

Miescher, P. \& Faucennet, M. (1954): L'ansorption du facteur L. E. par des noyaux cellulatires. Experientis, 10, 252.

Miescher, P. (1957): The antigenic constituents of the neutrophilic leucocyte with special 
reference to the L. E. phenomenon. Vox Sang., 2, 145.

Miescher, P. \& STRÄssle, R. (1957) : New serological methods for the detection of the L. E. factor. Vox Sang., 2, 283.

OUCHTERLONY, O. (1953) : Antigen-antibody reactions in gels. IV. Types of reactions in coordinated systems of diffusion. Acta Path. et Microbiol. Scand., 32, 231.

Pearson, C. M., Craddock, C. G. \& Simmons, N. S. (1958) : Complement fixation with DNA and leucocyte material in systemic lupus erythematosus. J. Lab. Clin. Med., 52, 580.

Robbins, W. C., Holman, H. R., Deicher, H. \& Kunkel, H. G. (1957) : Complement fixation with cell nuclei and DNAi n lupus erythematosus. Proc. Soc. Exp. Biol. Med., 96, 575.

SAINTE-MARIÈ, G. (1962) : A Paraffin embedding technique for studies employing immunofluorescence. J. Histochem. and Cytochem., 10, 250.

SEligmanN, M. (1958): Étudies immunologiques sur lupus érythémateux disseminé. Rev. Franc. Etudes Clin. Biol., 3, 558.

TAnenbaum, S. W. \& Beiser, S. M. (1963) : Pyrimidine-specific antibodies which react with deoxyribonucleis acid (DNA). Proc. Nat. Acad. Sci., 49, 662-668. 


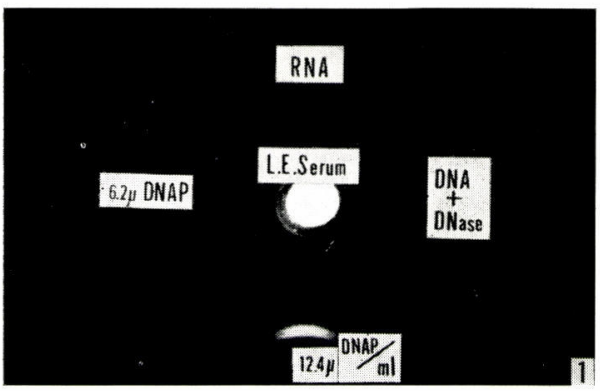

Plate-Fig. 1. A difinite wide band was observed in the Ouchterlony agar plate between SLE sera and $12.4 \gamma$ mole DNA P/ml solution. No band between patient's sera and DNA+DNase or RNA.

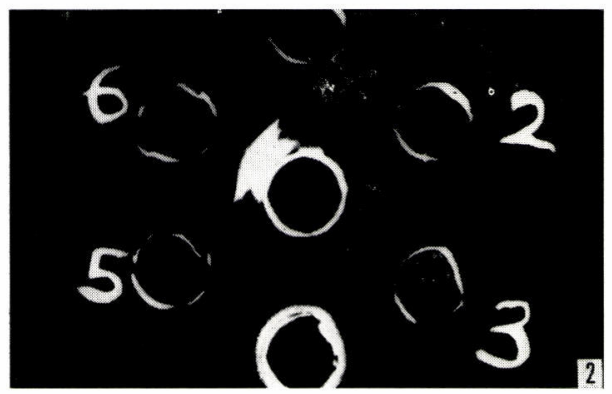

Plate-Fig. 2. Mother's serum of H. B. family reacts with DNA solution (6), no band between the serum and RNase (1), DNase (2), RNA (3), protamine (4), saline (5).

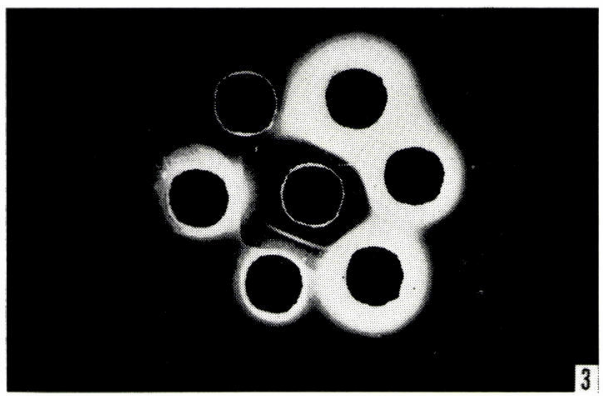

Plate-Fig. 3. Anticytoplasmic antibodies in SLE. The patient's serum (center well) reacts with mitochondrial fraction of the rat liver. 


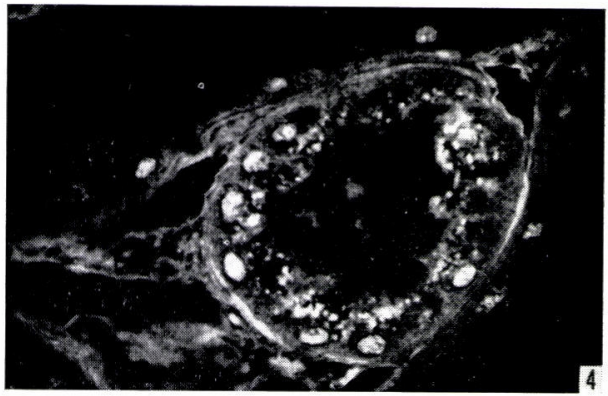

Plate-Fig. 4. SLE Kidney. Antinuclear staining in autologous tissue. Nuclei of the tubular epithelium and fine granules in the cytoplasm reacted with self serum by means of fluorescent antibody in direct method.

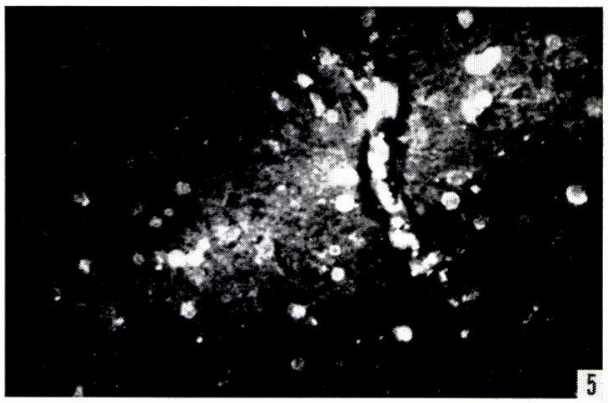

Plate-Fig. 5. Brain. Fine granules or granular aggregates like nuclear debris in the blood vessel lumen in the brain, and cytoplasm nerve cell reacted with patient's self serum.

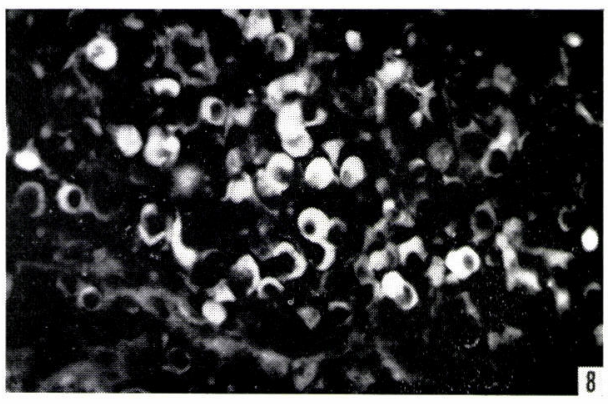

Plate-Fig. 8. SLE spleen. Most of the immune cells are plasmoblasts. Paraffin sections of SLE spleen were stained with anti SLE $7 \mathrm{~S}$ gamma-globulin conjugate. 

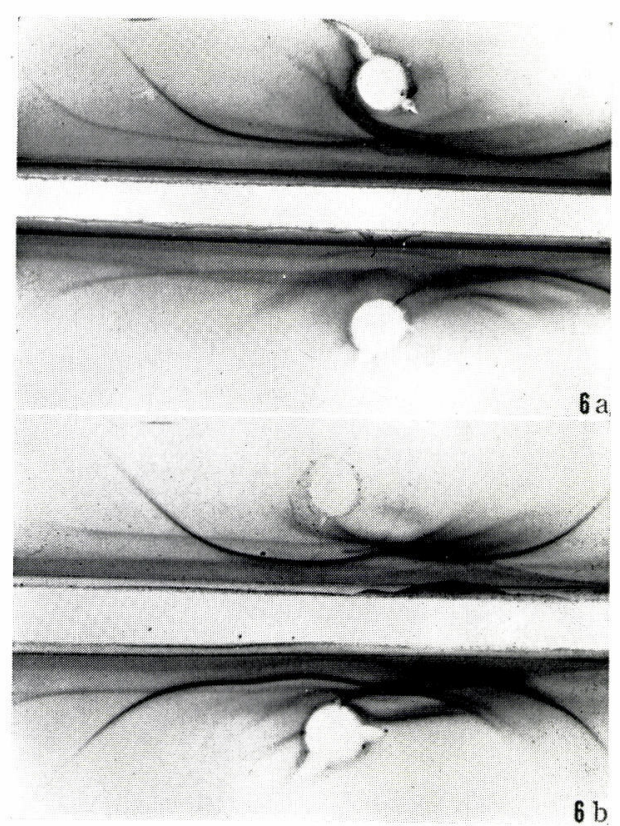

Plate-Fig. 6a. Shows that the antinuclear antibodies was absorbed completely with $18 \gamma \mathrm{DNAP} / \mathrm{ml}$ (lower site), upper site of this figure was the same serum before the treatment by DNA.

Plate-Fig. 6b. Shows no particular finding and absorption in the case of normal human serum before (upper site) and after (lower site) the DNA treatment as a control.

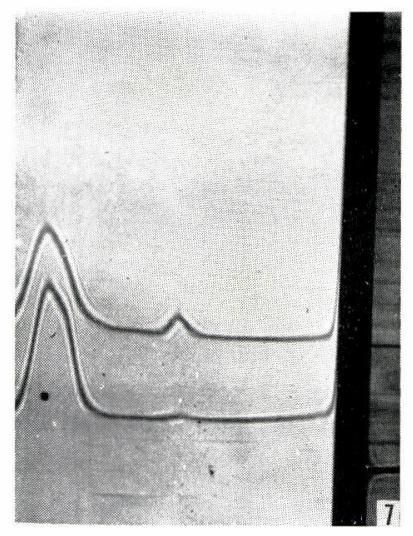

Plate-Fig. 7. 19S macroglobulin was demonstrated in SLE patient by ultracentrifuge method. 